\title{
Emission Reduction with Diesel Particle Filter with SCR Coating (SDPF)
}

\author{
Jan Czerwinski ${ }^{1}$ • Yan Zimmerli ${ }^{1}$ • Andreas Mayer ${ }^{2} \cdot$ Giovani D'Urbano $^{3}$. $^{\prime}$ \\ Daniel Zürcher ${ }^{3}$
}

Received: 12 November 2014 / Revised: 20 April 2015 / Accepted: 28 April 2015 /Published online: 21 May 2015

(C) Springer SIP, AG 2015

\begin{abstract}
The present paper informs about some results obtained with selective catalytic reduction (SCR) and with SDPF (a diesel particle filter (DPF) with SCR coating) on a medium duty research engine Iveco F1C. This work is a first attempt at evaluating the effects of a SDPF on non-legislated gaseous emissions and on secondary nanoparticles. Beside the limited gaseous emission components, $\mathrm{NH}_{3}, \mathrm{NO}_{2}$, and $\mathrm{N}_{2} \mathrm{O}$ were measured with FTIR, and the analysis of nanoparticle emissions was performed with Scanning Mobility Particle Sizer (SMPS) and condensation particle counter (CPC). The integration of functions of filtration and $\mathrm{NO}_{\mathrm{x}}$ reduction in one element of exhaust aftertreatment system offers several advantages and is widely investigated and considered as a market solution. The most important technical statements of the research are as follows:
\end{abstract}

- The emission behavior of SDPF after urea switch-on (SWON) concerning $\mathrm{NO}_{\mathrm{x}}$ reduction speed and $\mathrm{NH}_{3}$ peak

Jan Czerwinski

jan.czerwinski@bfh.ch

Yan Zimmerli

yan.zimmerli@bfh.ch

Andreas Mayer

ttm.a.mayer@bluewin.ch

Giovani D’Urbano

giovanni.durbano@bafu.admin.ch

Daniel Zürcher

daniel.zuercher@bafu.admin.ch

1 University of Applied Sciences, Biel-Bienne, AFHB, Gwerdtstrasse 5, 2560 Nidau, Switzerland

2 TTM Technik Thermische Maschinen, Fohrhölzlistrasse 14b, 5443 Niederrohrdorf, Switzerland

3 BAFU, Abt. Luftreinhaltung und Chemikalien, CH-3003 Bern, Switzerland is always fluctuating even in identical test procedures and with careful conducted conditionings.

- The loaded SDPF, compared with empty one, shows slower $\mathrm{NO}_{\mathrm{x}}$ reduction and higher $\mathrm{NH}_{3}$ after SWON because of use of part of $\mathrm{NO}_{2}$ for soot oxidation and consequently less $\mathrm{NO}_{2}$ availability for the deNO $\mathrm{N}_{\mathrm{x}}$ reactions; the secondary nanoparticle (NP) penetration after SWON is clearly lower with the loaded trap.

- Both investigated systems, SDPF and $2 \times$ SCR, attain nearly the same deNO $\mathrm{N}_{\mathrm{x}}$ efficiency.

- In worldwide heavy duty transient cycle (WHTC) with a lower level of exhaust gas temperature, SDPF causes lower deNO $\mathrm{x}_{\mathrm{x}}$ values (40-45 against $75 \%$ in European transient cycle (ETC)), but also lower $\mathrm{NH}_{3}$ emissions.

Further developments of those aftertreatment systems, concerning substrates, coatings, and reduction agent control, open further potentials of improvements.

Keywords Diesel emissions $\cdot$ Diesel particle filter $\cdot \mathrm{NO}_{\mathrm{x}}$ reduction $\cdot$ Exhaust after treatment $\cdot$ Non-legislated emissions $\cdot$ SCR coating on filter

$\begin{array}{ll}\text { Abbreviations } \\ \text { AFHB } & \text { Abgasprüfstelle FH Biel, CH } \\ \text { Air min } & \text { Stoichiometric air requirement } \\ \text { ASTRA } & \text { Amt für Strassen, CH, Swiss Road } \\ & \text { Authority } \\ \text { BAFU } & \text { Bundesamt für Umwelt, CH (FOEN) } \\ \text { CDI } & \text { Common rail diesel injection } \\ \text { cDPF } & \text { Catalytic DPF } \\ \text { CFPP } & \text { Cold filter plugging point } \\ \text { CLD } & \text { Chemoluminescence detector } \\ \text { CNC } & \text { Condensation nuclei counter }\end{array}$

Abbreviations

AFHB Abgasprüfstelle FH Biel, CH

Air min Stoichiometric air requirement

ASTRA Amt für Strassen, CH, Swiss Road

BAFU Bundesamt für Umwelt, $\mathrm{CH}$ (FOEN)

CDI Common rail diesel injection

cDPF Catalytic DPF

CFPP Cold filter plugging point

$\mathrm{CNC}$ Condensation nuclei counter 


\begin{tabular}{|c|c|}
\hline COND & $\begin{array}{l}\text { Conditioning procedure, here: } \\
2200 \mathrm{rpm} / 300 \mathrm{Nm}\end{array}$ \\
\hline $\mathrm{CPC}$ & Condensation particle counter \\
\hline $\mathrm{CR}$ & Common rail \\
\hline DOC & Diesel oxidation catalyst \\
\hline DI & Direct Injection \\
\hline DMA & Differential mobility analyzer \\
\hline DPF & Diesel particle filter \\
\hline EATS & Exhaust aftertreatment system \\
\hline ECU & Electronic control unit \\
\hline EGR & Exhaust gas recirculation \\
\hline EMPA & $\begin{array}{l}\text { Eidgenössische Material Prüf- und } \\
\text { Forschungsanstalt }\end{array}$ \\
\hline ETC & European Transient Cycle \\
\hline E4 & Engine version Euro 4 with EGR \\
\hline $\mathrm{E}(4)$ & Engine version Euro 4 without EGR \\
\hline $\mathrm{FE}$ & Filtration efficiency \\
\hline FID & Flame ionization detector \\
\hline FL & Full load \\
\hline FOEN & Federal Office of Environment \\
\hline FSN & Filter smoke number \\
\hline HD & Heavy duty \\
\hline ICE & Internal combustion engines \\
\hline INSOF & Insoluble fraction \\
\hline $\mathrm{K}_{\mathrm{x}}$ & $\begin{array}{l}\text { Conversion efficiency of the } \\
\text { component " } x "\end{array}$ \\
\hline $\mathrm{LD}$ & Low duty \\
\hline LDS & Laser diode spectrometer (for $\mathrm{NH}_{3}$ ) \\
\hline LRV & Luftreinhalteverordnung \\
\hline MD19 & Heated minidiluter \\
\hline NP & Nanoparticles $<999 \mathrm{~nm}$ (SMPS range) \\
\hline OEM & $\begin{array}{l}\text { Original equipment manufacturer } \\
\text { (here: w/o aftertreatment) }\end{array}$ \\
\hline OP & Operating point \\
\hline PAH & Polycyclic aromatic hydrocarbons \\
\hline $\mathrm{PC}$ & Particle counts \\
\hline PCFE & Particle counts filtration efficiency \\
\hline PM & Particulate matter, particle mass \\
\hline $\mathrm{PN}$ & Particle number \\
\hline PSD & Particle size distribution \\
\hline RAI & Reduction agent injection (AdBlue) \\
\hline $\mathrm{RE}$ & Reduction efficiency \\
\hline SCR & Selective catalytic reduction \\
\hline SDPF & DPF with SCR coating \\
\hline SL & Soot loading procedures \\
\hline SMPS & Scanning Mobility Particle Sizer \\
\hline SOF & Soluble organic fraction \\
\hline SOI & Start of injection \\
\hline $\mathrm{SP}$ & Sampling position \\
\hline SV & Spatial velocity \\
\hline SW & Switch on urea \\
\hline SWON & Urea switch-on \\
\hline $\mathrm{TC}$ & Thermoconditioner \\
\hline
\end{tabular}

\begin{tabular}{|c|c|}
\hline TDC & Top dead center \\
\hline TTM & Technik Thermische Maschinen \\
\hline UDS & Urea dosing system \\
\hline ULSD & Ultra low sulfur diesel \\
\hline VERT & $\begin{array}{l}\text { Verminderung der Emissionen von Realmaschinen } \\
\text { in Tunelbau }\end{array}$ \\
\hline & Verification of Emissions Reduction Technologies \\
\hline
\end{tabular}

\section{Introduction and Objectives}

\subsection{DPF+SCR}

The combination of particle filtration (diesel particle filter, DPF) and of the most efficient deNO $\mathrm{x}_{\mathrm{x}}$ technology (selective catalytic reduction, SCR) is widely considered as the most efficient solution, up to date, to minimize the emissions of diesel engines. With a DPF a very efficient elimination of solid particles (particle counts filtration efficiency (PCFE) up to $99.99 \%$ ) and with SCR a substantial reduction of $\mathrm{NO}_{\mathrm{x}}$ $\left(\mathrm{K}_{\mathrm{NOx}}\right.$ over $\left.90 \%\right)$ are possible. Intense developments are on the way by the original equipment manufacturers (OEMs), and investigations were performed [1-11].

The removal of $\mathrm{NO}_{\mathrm{x}}$ from the lean exhaust gases of diesel engines (also lean-burn gasoline engines) is an important challenge. Selective catalytic reduction (SCR) uses a supplementary substance - reduction agent - which in presence of catalysts produces useful reactions transforming $\mathrm{NO}_{\mathrm{x}}$ in $\mathrm{N}_{2}$ and $\mathrm{H}_{2} \mathrm{O}$.

The preferred reduction agent for toxicological and safety reasons is the water solution of urea (AdBlue), which due to reaction with water (hydrolysis) and due to thermal decomposition (thermolysis) produces ammonia $\mathrm{NH}_{3}$, which is the chemically reacting reduction substance.

A common configuration of $\mathrm{SCR} \mathrm{deNO}_{\mathrm{x}}$ system consists of four catalytic activities:

- Precatalyst converting $\mathrm{NO}$ to $\mathrm{NO}_{2}$ (with the aim of 50/50 proportion; a part used in the present investigations)

- Injection of AdBlue (with the intention of best distribution and evaporation in the exhaust gas flow)

- Hydrolysis catalyst (production of $\mathrm{NH}_{3}$ )

- Selective catalyst (several deNO $\mathrm{N}_{\mathrm{x}}$ reactions)

- Oxidation catalyst (minimizing of $\mathrm{NH}_{3}$ slip)

In the exhaust aftertreatment systems (EATSs) actually in use, several functions can be integrated in one catalyst. In the tested systems, the hydrolysis and the SCR reactions occurred in the SCR catalysts or in the SDPF (DPF with SCR coating). There was no ammonia slip catalyst applied.

The main deNO $\mathrm{x}_{\mathrm{x}}$ reactions between $\mathrm{NH}_{3}, \mathrm{NO}$, and $\mathrm{NO}_{2}$ are widely mentioned in the literature $[9,11-14]$. Depending on 
the temperature of gas and catalysts, space velocity, and stoichiometry, these reactions progress more or less rapidly. During the transient engine operation, a complex situation of reactions is created with varying intensities in time and space.

Additionally, there are temperature windows for catalysts and cutoff of the AdBlue injection at low exhaust gas temperatures to prevent the deposits of residues.

Several side reactions and secondary substances are present. An objective is to minimize the tail pipe emissions of ammonia $\mathrm{NH}_{3}$, nitrous oxide $\mathrm{N}_{2} \mathrm{O}$, isocyanic acid $\mathrm{HNCO}$, and ammonium nitrate $\mathrm{NH}_{4} \mathrm{NO}_{3}$ (also known as secondary nanoparticles).

Intense research about the solutions of problems of the present systems and about new developments has been reported. The following can be mentioned:

- Deposits of urea-related substances (urea, cyanuric acid, ammonium nitrate) [13-15]; these deposits create undesirable effects of store-release of reactants, of heterogenous reactivity, and in worst case of plugging the EATS.

- Measuring accuracy of $\mathrm{NO}_{\mathrm{x}}$ in presence of $\mathrm{NH}_{3}$ [16-18]; highly reactive $\mathrm{NH}_{3}$ may create problems of measuring accuracy and may deteriorate the exactitude of chemoluminescence detector (CLD).

- Other reduction agents $[19,20]$ were proposed in order to introduce gaseous $\mathrm{NH}_{3}$ in the exhaust line or to obtain higher storage capacity of $\mathrm{NH}_{3}$ precursors on board of vehicle.

- AdBlue dosing and homogenous distribution [21]; an attribute of improving the use of urea in the sense: more deNO $\mathrm{x}_{\mathrm{x}}$ reactivity, less $\mathrm{NH}_{3}$ slip.

- Construction variants of DPF+SCR and their influences on functionality, warm-up, DPF regeneration, and durability of elements [8-10].

\subsection{SDPF}

There are efforts and research of integrating the functions of filtration and $\mathrm{NO}_{\mathrm{x}}$ reduction in one element, [22-26]. This is designed as SCR on filter (SCRoF) or SCRF, or SDPF.

There are several advantages of this solution:

The flow-through SCR substrate is eliminated and there is, in most cases, a lower volume of the system. Due to the lower volume, there is a reduced thermal capacity and a quicker warm-up. There can also be lower costs of the coatings [25, 27].

In order to increase the $\mathrm{NO}_{\mathrm{x}}$ conversion, especially at cold start- and warm-up conditions, a supplementary flow-through SCR catalyst can be applied downstream of SDPF and the last one can be placed nearer to the engine. The more rapid heat-up of SDPF would enable an earlier urea dosing and consequently an improved $\mathrm{NO}_{\mathrm{x}}$ control.
The $\mathrm{NO}_{2}$, which is generated in the oxidation catalyst, is used for both the continuous soot oxidation and the SCR reactions.

One of the biggest challenges of the research is to identify the optimal trade-off between these activities and to be able to adapt the filter component design for specific engine applications.

In the present work, as well as in the cited literature, it has been shown, that similar $\mathrm{NO}_{\mathrm{x}}$ reduction rates may be reached with the integrated (SDPF) systems and with the conventional SCR, $[23,25,26]$.

\subsection{Objectives}

A general objective of the paper is to present some specific observations, concerning the urea switch-on (SWON) with different soot loads. These observations are helpful in order to understand better and to compare the emissions and passive regeneration behavior of a conventional (DPF+SCR) system with a SDPF system. The research was performed at certain repeated operating conditions and, consequently, it cannot be generalized for other applications and requirements.

During the project, the dynamic urea dosing was prepared and the tests were performed at steady state (steps-tests) and in dynamic operation (worldwide heavy duty transient cycle, WHTC).

The topics presented in this paper are the following:

- Repetitivity of $\mathrm{NO}_{\mathrm{x}} / \mathrm{NH}_{3}$ emissions after urea switch-on (SWON)

- Nanoparticle emissions after SWON

- $\mathrm{deNO}_{\mathrm{x}}$ efficiencies

- Dynamic operation

\section{Tested Engine, Fuel, and Lubricant}

\subsection{Test Engine}

\begin{tabular}{ll}
\hline Manufacturer: & Iveco, Torino Italy \\
Type: & F1C Euro 3/Euro 4 \\
Displacement: & $3.00 \mathrm{~L}$ \\
RPM: max. & $4200 \mathrm{rpm}$ \\
Rated power: & $100 \mathrm{~kW} @ 3500 \mathrm{rpm}$ \\
Model: & 4 cylinder in-line \\
Combustion process: & direct injection \\
Injection system & Bosch Common Rail 1600 bar \\
Supercharging: & Turbocharger with intercooling \\
Emission control: & none \\
Development period: & until 2000 (Euro 3) \\
\hline
\end{tabular}


Figure 1 shows the engine in the laboratory for IC-engines, University of Applied Sciences, Biel-Bienne, CH.

\subsection{Fuel}

The following diesel fuel was used for the research (Table 1):

- Shell Formula Diesel fuel Swiss market summer quality (10 ppm S) according to SN EN 590

Table 1 represents the most important data of the fuel according to the standards.

\subsection{Lubricant}

For all tests, a lube oil according to the manufacturer requirements, Mobil 1 ESP Formula 5W-30, was used.

Table 2 shows the available data of this oil,

ACEA classes: C3, A3, B3/B4,

API classes: SL / SM; CF

\subsection{Engine Version Euro 4}

In collaboration with the engine manufacturer, the research engine version Euro 3 was upgraded to the version Euro 4. The new engine equipment consisted of the following:

- Exhaust gas recirculation (EGR) valve (high pressure EGR) (see Fig. 2)

- EGR cooler

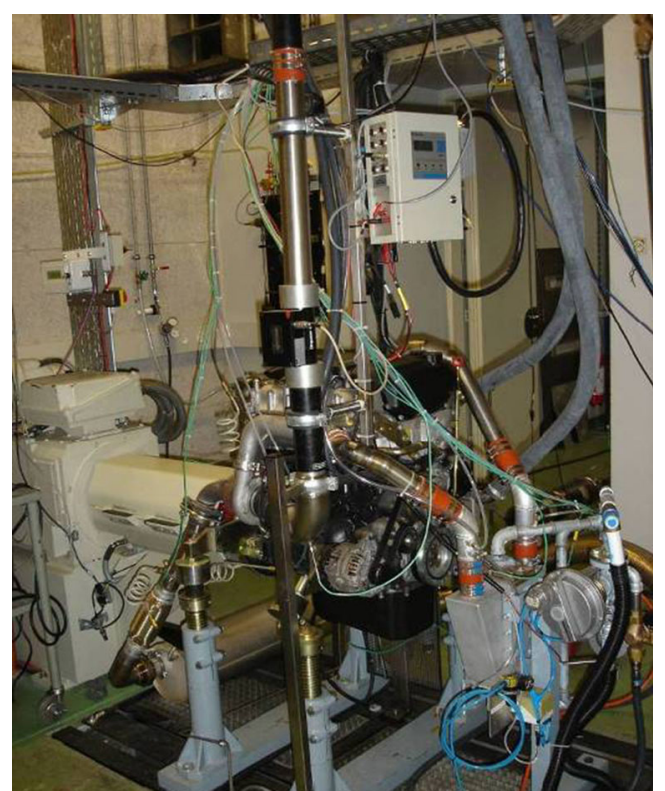

Fig. 1 IVECO engine F1C and dynamic engine dynamometer in the engine room
Table 1 Fuel properties as per EU standards

\begin{tabular}{|c|c|c|}
\hline & & Diesel \\
\hline Density $15^{\circ} \mathrm{C}$ & $\mathrm{g} / \mathrm{mL}$ & 0.832 \\
\hline Viscosity at $40{ }^{\circ} \mathrm{C}$ & $\mathrm{mm}^{2} / \mathrm{s}$ & $2.0-4.5$ \\
\hline \multicolumn{2}{|l|}{ Flash point } & above $55^{\circ} \mathrm{C}$ \\
\hline \multicolumn{2}{|l|}{ Cloud point } & $\max -10^{\circ} \mathrm{C}$ \\
\hline \multicolumn{2}{|l|}{ Filterability CFPP } & $\max -20^{\circ} \mathrm{C}$ \\
\hline Ash & $\%$ & $\max 0.010$ \\
\hline Sulfur & ppm & $<10$ \\
\hline \multicolumn{2}{|l|}{ Cetane number } & 51 \\
\hline Calorific value & $\mathrm{MJ} / \mathrm{kg}$ & 42.7 \\
\hline $\mathrm{C}$ fraction & in $\%$ & 86.7 \\
\hline $\mathrm{H}$ fraction & in $\%$ & 13.3 \\
\hline O fraction & in $\%$ & 0 \\
\hline $\mathrm{Air}_{\min }$ & $\mathrm{kg} / \mathrm{kg}$ & 14.52 \\
\hline \multicolumn{2}{|c|}{ Boiling range $10-90 \%{ }^{\circ} \mathrm{C}$} & $180-340$ \\
\hline
\end{tabular}

CFPP cold filter plugging point

- Throttle valve at intake,

- Air mass flowmeter at intake

- Injectors

- New engine calibration (electronic control unit, ECU) for modifications of injection timing and injection mode (pre-/post-injections)

The principal influences on engine combustion and emissions are as follows:

- HP EGR regulated continuously in the engine map

Table 2 Data of the utilized oil (* analysis, others: specifications)

\begin{tabular}{lll}
\hline Property & Mobil oil & \\
\hline Viscosity kin $40{ }^{\circ} \mathrm{C}$ & 72.8 & $\mathrm{~mm}^{2} / \mathrm{s}$ \\
Viscosity kin $100{ }^{\circ} \mathrm{C}$ & 12.1 & $\mathrm{~mm}^{2} / \mathrm{s}$ \\
Viscosity index & 164 & $(-)$ \\
Density $15{ }^{\circ} \mathrm{C}$ & 0.85 & $\mathrm{~kg} / \mathrm{m}^{3}$ \\
Pourpoint & -45 & ${ }^{\circ} \mathrm{C}$ \\
Flamepoint & 254 & ${ }^{\circ} \mathrm{C}$ \\
Total base number, TBN* & 6 & $\mathrm{mg} \mathrm{KOH} / \mathrm{g}$ \\
Sulfur ashes* & 600 & $\mathrm{mg} / \mathrm{kg}$ \\
Sulfur* & 2000 & $\mathrm{mg} / \mathrm{kg}$ \\
$\mathrm{MG}^{*}$ & 41 & $\mathrm{mg} / \mathrm{kg}$ \\
$\mathrm{MO}^{*}$ & 80 & $\mathrm{mg} / \mathrm{kg}$ \\
$\mathrm{Zn}^{*}$ & 900 & $\mathrm{mg} / \mathrm{kg}$ \\
$\mathrm{Ca}^{*}$ & 1100 & $\mathrm{mg} / \mathrm{kg}$ \\
$\mathrm{P}^{*}$ & 820 & $\mathrm{mg} / \mathrm{kg}$ \\
\hline
\end{tabular}


Fig. 2 Engine dynamometer and test equipment

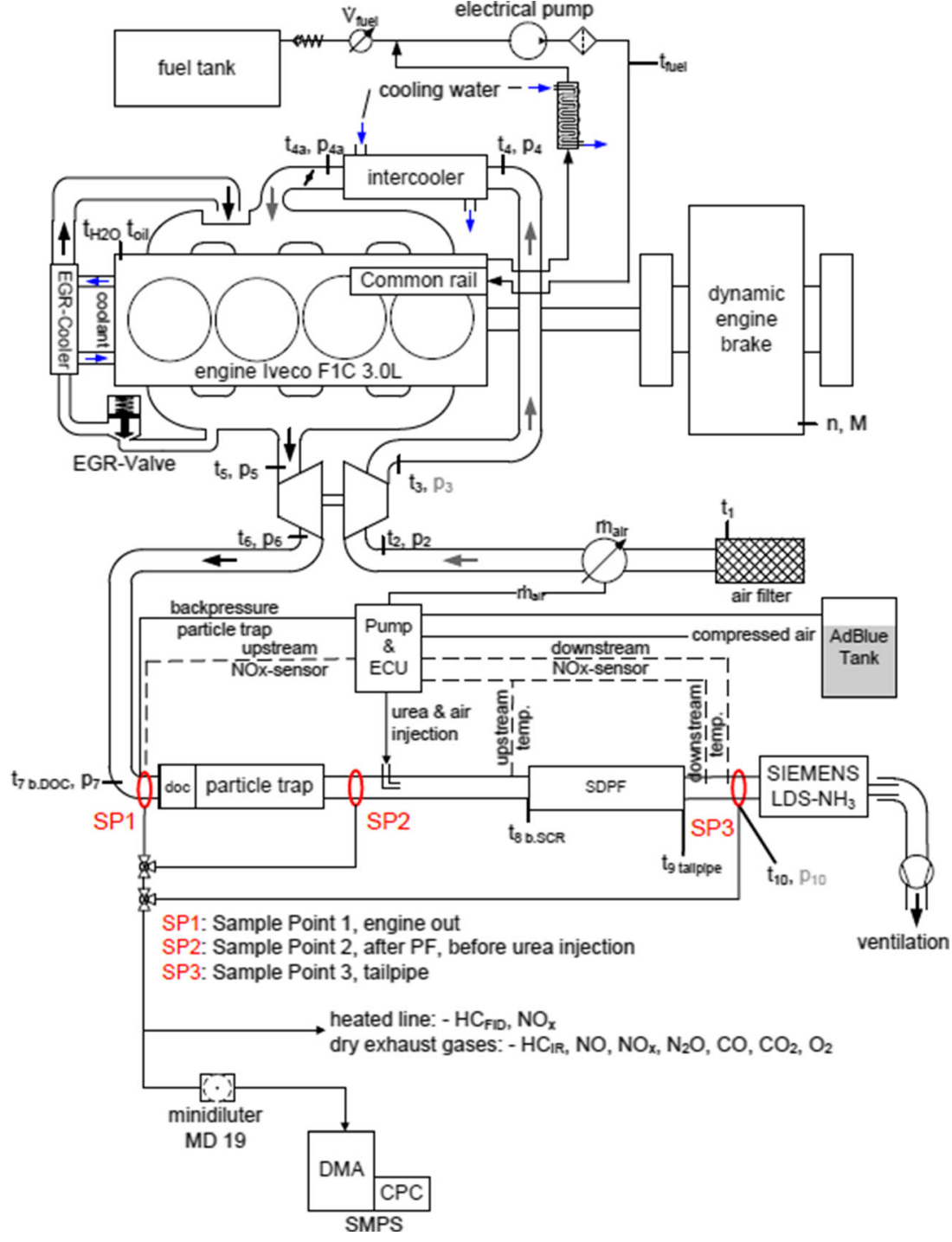

- Further use of potentials of CR injection system (pressure, timing, shaping, strategies)

The EGR is regulated by means of simultaneous positioning of the EGR valve and of the throttle valve with air mass flow as guiding parameter. The total injected fuel quantity is adapted to the air mass flow.

The ECU engine calibration is given in two versions: for HD and for LD application. In the present work, only the HD version was used.

The research laboratory received access to the ECU with the possibility of switching on/off EGR.

The engine version Euro 4 with EGR is abbreviated to E4 in this paper and the same version with EGR switched off is called E(4).

\section{Measuring Setup and Instrumentation}

\subsection{Engine Dynamometer and Standard Test Equipment}

Figure 2 represents the special systems installed on the engine, or in its periphery for analysis of the regulated and unregulated emissions.

Laboratory equipment employed:

- Dynamic test bench Kristl \& Seibt

- Tornado Software Kristl \& Seibt

- Fuel flow measurement AIC 2022

- Air mass meter ABB Sensiflow P

- Pressure transducers Keller KAA-2/8235, PD-4/8236

- Thermo-couples Type K. 


\subsection{Test Equipment for Exhaust Gas Emissions}

Measurement is performed according to the exhaust gas emission regulations for heavy duty vehicles which are in force in Switzerland (Directive 2005 / 55 / CE \& ISO 8178):

- Volatile components:

- Horiba exhaust gas measurement devices

Type: VIA-510 for $\mathrm{CO}_{2}, \mathrm{CO}, \mathrm{HCIR}, \mathrm{O}_{2}$, Type: CLA-510 for $\mathrm{NO}, \mathrm{NO}_{\mathrm{x}}$

- Amluk exhaust gas measurement device Type:

FID 2010 for HCFID,

- $\mathrm{NH}_{3}$ and $\mathrm{N}_{2} \mathrm{O}$ :

With SCR, several unregulated and secondary pollutants can be produced. The slip of gaseous components such as ammonia $\mathrm{NH}_{3}$ and nitrous oxide $\mathrm{N}_{2} \mathrm{O}$ was measured by means of

- Siemens LDS 6 Laser Analyzer 7MB 6021, $\mathrm{NH}_{3}$

- Siemens ULTRAMAT 6E 7MB2121, $\mathrm{N}_{2} \mathrm{O}$

- Eco physics CLD $822 \mathrm{CM}$ hr with hot line for $\mathrm{NO}, \mathrm{NO}_{2}$, $\mathrm{NO}_{3}, \mathrm{NH}_{3}$

\subsection{Particle Size Analysis}

The distribution of the particle size and number was analyzed with the following apparatus:

- SMPS - Scanning Mobility Particle Sizer, TSI (DMA TSI 3081, CPC TSI $3010 \mathrm{~A}$ )

- NanoMet - dilution system consisting of

- MD19 tunable minidiluter (Matter Eng. MD19-2E) heated up to $80^{\circ} \mathrm{C}$

- thermoconditioner (TC) - heated up to $300{ }^{\circ} \mathrm{C}$.

The nanoparticle results represented in this paper are obtained with sampling at tail pipe with MD19 and with thermoconditioner. The nanoparticulate measurements were performed at constant engine speed (warm) with SMPS and in dynamic cycles with CPC.

\section{Test Procedures on Engine Dynamometer}

The stationary testing is performed by different constant operating points (OPs) of the engine. These OPs are chosen at $2200 \mathrm{rpm}$ (intermediate speed) and at different loads; see Fig. 3. The sequence of OPs with increasing load and with increasing exhausts gas temperature is called regeneration steps-test.

In the first part of the works, the step duration was $20 \mathrm{~min}$ per step. This caused a total oxidation of the particle matter (PM) loading in the highest steps. For investigations of regeneration efficiency by mass with different changed conditions (like soot load, or reduction agent injection (RAI) on/off), it was decided in the further works to apply a shorter step duration of $10 \mathrm{~min}$, to enable a better differentiation of the results.

At lower load, with exhaust temperature before SCR lower than $200^{\circ} \mathrm{C}$, the urea dosing is stopped.

As conditioning (COND) a constant OP, $2200 \mathrm{rpm} / 300 \mathrm{Nm}$ was used to purge the SDPF concerning the soot load and the ammonia storage.

DPF soot loading (SL) was performed according to a fixed schedule at part load OP of the engine, $2200 \mathrm{rpm} / 50 \mathrm{Nm}$ and with adapted engine parameters (ECU load mode)-lower injection rail pressure, earlier injection timing, and activated EGR. An example of this setting at one OP is given in Table 3.

DPF fully pre-loaded means the increase of mass (weight at $\left.140^{\circ} \mathrm{C}\right)$ by $20.9 \mathrm{~g}(3.5 \mathrm{~g} / \mathrm{L})$ in average; half pre-loaded means the one half of this PM charge and "filter empty" is after the conditioning (COND).

The urea dosing system (UDS) consists of an AdBlue tank, a pump, an ECU, and an injector. The injector is attached to the pressurized air and the injection jet is air-shrouded to minimize the deposits. The dynamic dosing of AdBlue was performed by means of the control units: of the engine dynamometer and of the Albonair dosing system with the input of the $\mathrm{NO}_{\mathrm{x}}$ sensor "engine out" signals; see scheme Fig. 4.

For dynamic testing, the cycles WHTC and ETC were used (Fig. 5).

\section{Exhaust Aftertreatment Systems}

The exhaust aftertreatment systems (EATSs) were set in modular way in the exhaust line of the engine.

Table 4 shows the EATSs, which are presented in this paper. The elements diesel oxidation catalyst (DOC), catalytic DPF (cDPF), and SCR were placed for the research in the straight in-line configurations, and this Table 4 replaces a possible scheme representation. The material of substrates of DOC, cDPF, and SDPF is cordierite.

Table 5 shows some data of the investigated elements. The $\mathrm{SCR}$ coatings were Fe-based. There is no further information about all applied coatings.

For research of SCR efficiencies with SDPF in some test series, a cDPF was used upstream of SDPF in order to eliminate any influence of particles on the SDPF $\mathrm{NO}_{\mathrm{x}}$ reduction rate. This test system is called SYS05.

Due to equal active volumes of $2 \times$ SCR and SDPF elements, similar spatial velocities result in the engine operation. 
Fig. 3 Engine map of the Iveco F1C engine and tested OPs

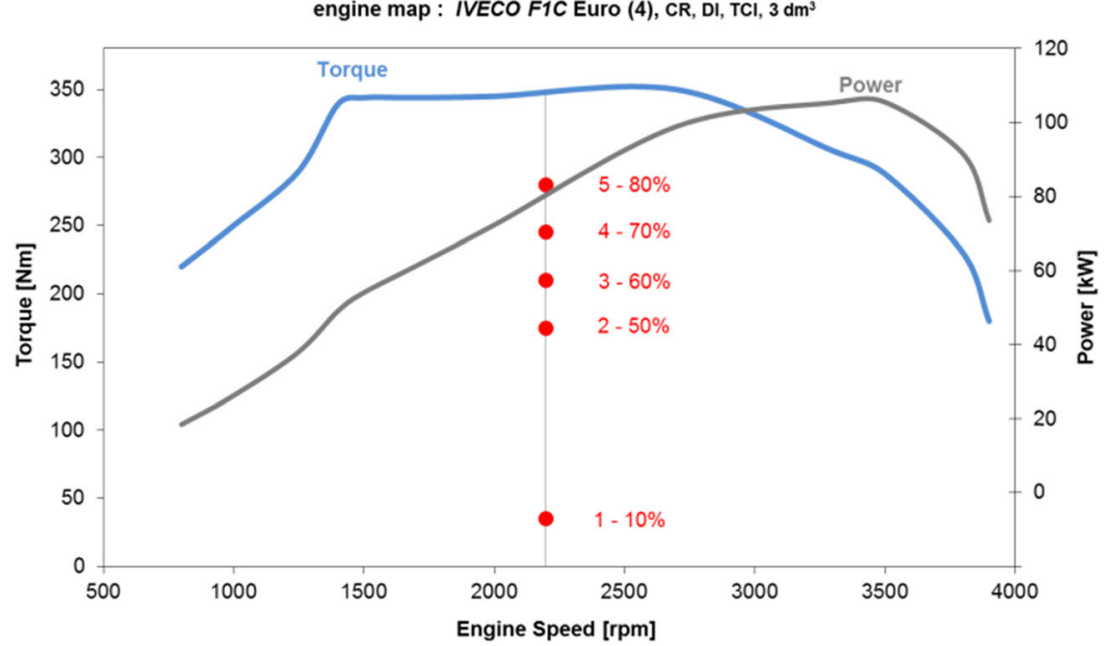

Table 6 summarizes the spatial velocities (SVs) in the stepstest with consideration of different exhaust gas temperatures.

\section{Results}

Below, the results of some specific research subjects are presented. These subjects are chosen out of many results of a 2year project. Even if these results are connected with the given test material of EATS and with the test procedures of this work, the authors believe that they may complete or enlarge the present state of knowledge.

\subsection{Repetitivity of $\mathrm{NO}_{\mathbf{x}} / \mathrm{NH}_{3}$ Emissions After Erea Switch-on}

Figure 6 shows the first comparison of emissions in steps-tests with different soot loadings of the SDPF (full, half, empty) and with active RAI. After urea switch-on (SWON), there is a reduction of $\mathrm{NO}_{\mathrm{x}}$ concentration and a peak of $\mathrm{NH}_{3}$. This $\mathrm{NH}_{3}$ peak declines to a lower average value in further steps. With higher soot load, this average $\mathrm{NH}_{3}$ concentration increases. The reduction speed of $\mathrm{NO}_{\mathrm{x}}$ after SWON correlates with the

Table 3 Adaptation of engine parameters for quicker soot loading

\begin{tabular}{lll}
\hline $2200 \mathrm{rpm} / 50 \mathrm{Nm}$ & $\begin{array}{l}\text { Original } \\
\text { (reference) }\end{array}$ & Adapted \\
\hline FSN [-] & 0.5 & 2.2 \\
T. b. cDPF $\left({ }^{\circ} \mathrm{C}\right)$ & 197 & 243 \\
Rail pressure (bar) & 600 & 300 \\
Inj. b. TDC $\left({ }^{\circ} \mathrm{CA}\right)$ & 5.7 & 9.5 \\
Air flow $(\mathrm{mg} / \mathrm{hub})$ & 750 & 500 \\
EGR & Closed & Active \\
\hline
\end{tabular}

$c D P F$ catalytic diesel particle filter, $T D C$ top dead center, $E G R$ exhaust gas recirculation soot load in the sense: more soot load, lower reduction rate of $\mathrm{NO}_{\mathrm{x}}$. This is to explain with less $\mathrm{NO}_{2}$ production on the sootloaded catalytic surface (DOC) and more $\mathrm{NO}_{2}$ consumption for the soot oxidation. Less availability of $\mathrm{NO}_{2}$ in the deNO reactions causes more $\mathrm{NH}_{3}$.

The $\mathrm{NH}_{3}$ peaks in Fig. 6 do not follow the sequence of soot load, and it was not clear if the $\mathrm{NH}_{3}$ peaks after SWON are repetitive or varying from test to test. Most probably, they are extremely influenced by the initial state of the SDPF (local distribution and amounts of soot load, urea, and $\mathrm{NH}_{3}$ storage). This question was considered in further tests (see Fig. 7).
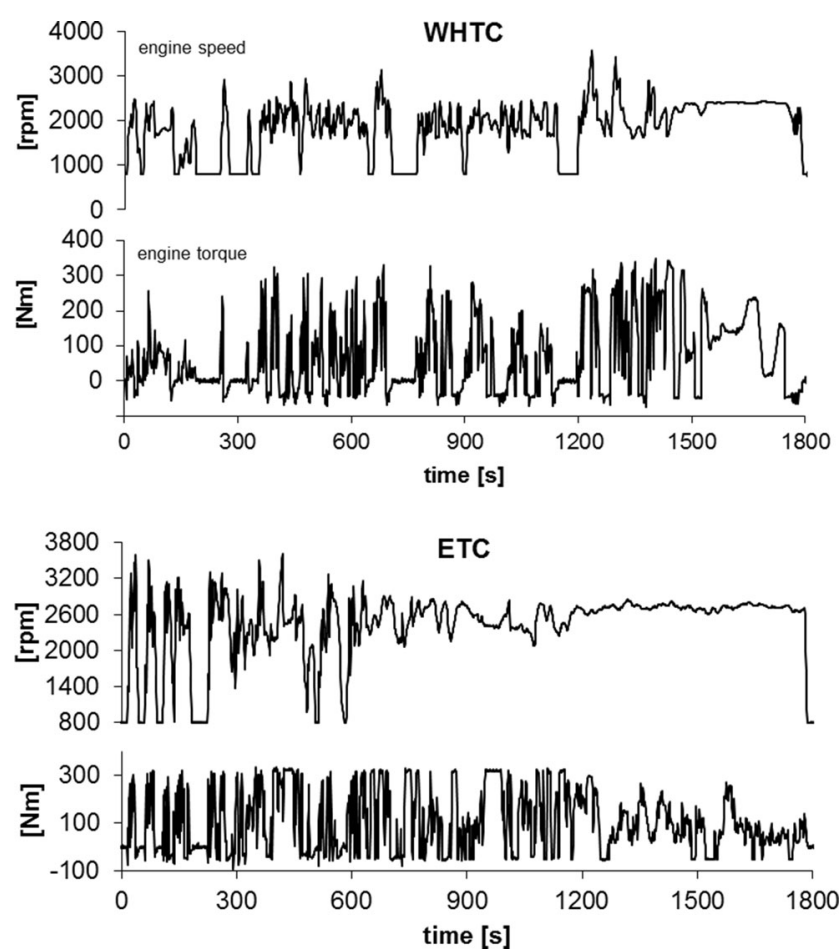

Fig. 4 Implementation of AdBlue dosing control over the engine test bench 


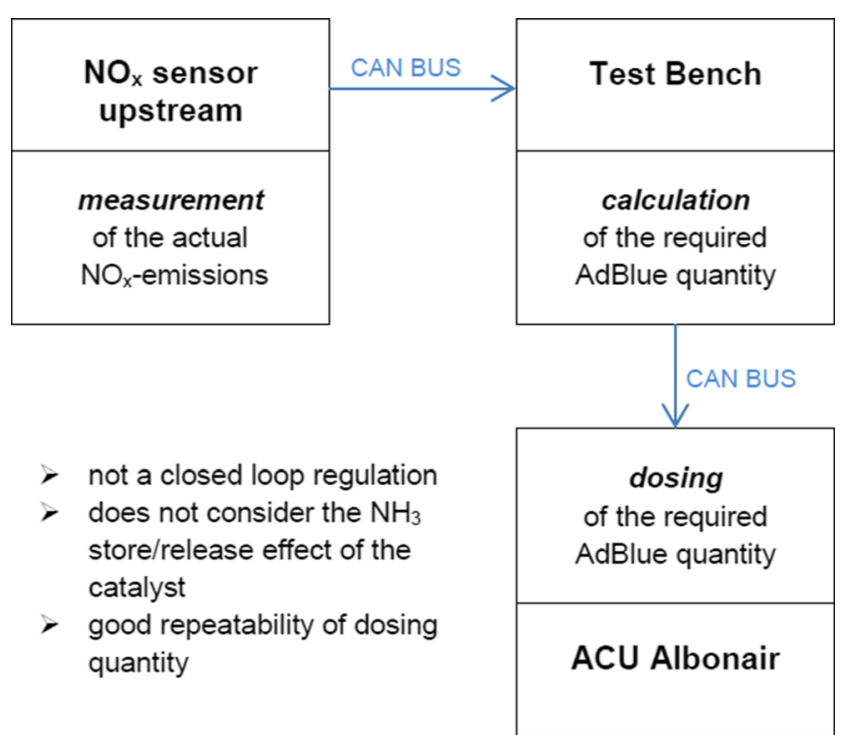

Fig. 5 Engine torque and speed in the WHTC and ETC (Iveco F1C, $3.01)$

With active RAI, the nanoparticle (NP) emissions increase after the start of urea injection, indicating the contribution of urea products to the emission. With loaded trap, the NP filtration efficiency is as usually increased and the emitted concentrations of secondary NP, which pass the trap, are lower.

The additional tests about emissions after SWON were performed with the empty SDPF (always after conditioning procedure). Figure 7 shows in the higher part the magnified representation of $\mathrm{NO}_{\mathrm{x}}$ and $\mathrm{NH}_{3}$ courses from Fig. 6 with addition of another repetition with empty SDPF. The repetition shows a slower drop of $\mathrm{NO}_{\mathrm{x}}$ and a higher peak value of $\mathrm{NH}_{3}$, than the previous attempt with not pre-loaded filter.

In the lower part of Fig. 7, three successive switch-on attempts with not pre-loaded filter are represented. These results confirm the tendency that the cases with quicker $\mathrm{NO}_{\mathrm{x}}$ drop after $\mathrm{SWON}$ have also a lower $\mathrm{NH}_{3}$ emission.

In the presented example of three SWON attempts with empty filter, there is a sequence of results (d), (e), and (f) indicating an increasing deNO$_{\mathrm{x}}$ reactivity. This in turn can be explained with more complete oxidation of residual soot from the filter in the later attempts.

If the filter soot load is added, then the amount of soot and the distribution of soot residues in the filter volume have an

Table 4 Variants of exhaust aftertreatment systems

\begin{tabular}{|c|c|}
\hline System & Elements \\
\hline SYS01 & $\mathrm{DOC}_{\mathrm{cDPF}} \mathrm{SCR} \mathrm{SCR}$ \\
\hline SYS03 & $\mathrm{DOC}_{\Delta} \mathrm{SDPF}$ \\
\hline SYS05 & $\mathrm{DOC} \mathrm{CDPF}_{\Delta} \mathrm{SDPF}$ \\
\hline
\end{tabular}

$\triangle$ position of RAI, DOC diesel oxidation catalyst, $c D P F$ catalytic diesel particle filter, $S C R$ selective catalytic reduction
Table 5 Data of investigated elements

\begin{tabular}{llll}
\hline Element & Porosity & Wall thickness & Dimensions \\
\hline DOC & $400 \mathrm{cpsi}$ & $4.3 \mathrm{mil}$ & $6.77 \times 3.5$ in \\
SCR & $400 \mathrm{cpsi}$ & $4.3 \mathrm{mil}$ & $6.77 \times 5 \mathrm{in}$ \\
$\mathrm{cDPF}$ & $300 \mathrm{cpsi}$ & $12 \mathrm{mil}$ & $6.77 \times 10 \mathrm{in}$ \\
SDPF & $300 \mathrm{cpsi}$ & $12 \mathrm{mil}$ & $6.77 \times 10 \mathrm{in}$ \\
\hline
\end{tabular}

$D O C$ diesel oxidation catalyst, $c D P F$ catalytic diesel particle filter, $S C R$ selective catalytic reduction, SDPF DPF with SCR coating

influence on the chemical reactions, their speed, stoichiometry, and local availability of reactants, especially of $\mathrm{NO}_{2}$.

In general, the differences of reactivity between the SWON attempts can be a result of heterogeneous distribution of urea and soot in the SDPF volume, which causes the variances of $\mathrm{NO}_{2}$ availability at the same operating conditions with identical history of the precedent operating collectives.

According to the investigations with filter weighing (not represented in this paper), there are indications of soot load being heterogeneously distributed and causing different relationships between backpressure and the stored soot mass in diverse identical soot loading procedures. This has an impact on the local $\mathrm{NO}_{2}$ availability and consequently on the deNO reactions and on the possible $\mathrm{NH}_{3}$ slip. This local impact is supposed to be similar, as the global influence (see Fig. 8): more soot $\rightarrow$ less availability of $\mathrm{NO}_{2}$ for deNO $\mathrm{N}_{\mathrm{x}}$, slower rate of $\mathrm{NO}_{\mathrm{x}}$ reduction, and higher probability of ammonia slip.

In summary, we can assert that the emission behavior of SDPF after urea SWON concerning $\mathrm{NO}_{\mathrm{x}}$ reduction speed and $\mathrm{NH}_{3}$ peak is always fluctuating even after identical procedures of soot loading and/or conditioning.

As per the presented results and their explanations, the authors declare that the reasons of this dispersion are the inhomogeneity of urea (and urea products) distribution and the varying initial state of filter in respect of soot loading and soot distribution in the filter volume.

Figure 9 represents the results with not pre-loaded (empty) SDPF with RAI.

Table 6 Spatial velocities in SCR and SDPF during the steps-test

\begin{tabular}{|c|c|c|c|c|c|}
\hline \multirow[b]{2}{*}{$\begin{array}{l}\mathrm{M} \\
(\mathrm{Nm})\end{array}$} & \multirow[b]{2}{*}{$\begin{array}{l}\mathrm{m}_{\text {exh. }} \\
(\mathrm{kg} / \mathrm{h})\end{array}$} & \multicolumn{4}{|c|}{ Spatial velocities } \\
\hline & & $\begin{array}{l}\text { DOC } \\
(1 / s)\end{array}$ & $\begin{array}{l}\text { SDPF } \\
(1 / \mathrm{s})\end{array}$ & $\begin{array}{l}\mathrm{cDPF} \\
(1 / \mathrm{s})\end{array}$ & $\begin{array}{l}2 \mathrm{xSCR} \\
(1 / \mathrm{s})\end{array}$ \\
\hline 35 & 223 & 38 & 13 & 13 & 13 \\
\hline 175 & 293 & 67 & 24 & 24 & 23 \\
\hline 210 & 312 & 74 & 26 & 27 & 26 \\
\hline 245 & 334 & 83 & 29 & 30 & 28 \\
\hline 280 & 355 & 92 & 32 & 33 & 31 \\
\hline
\end{tabular}




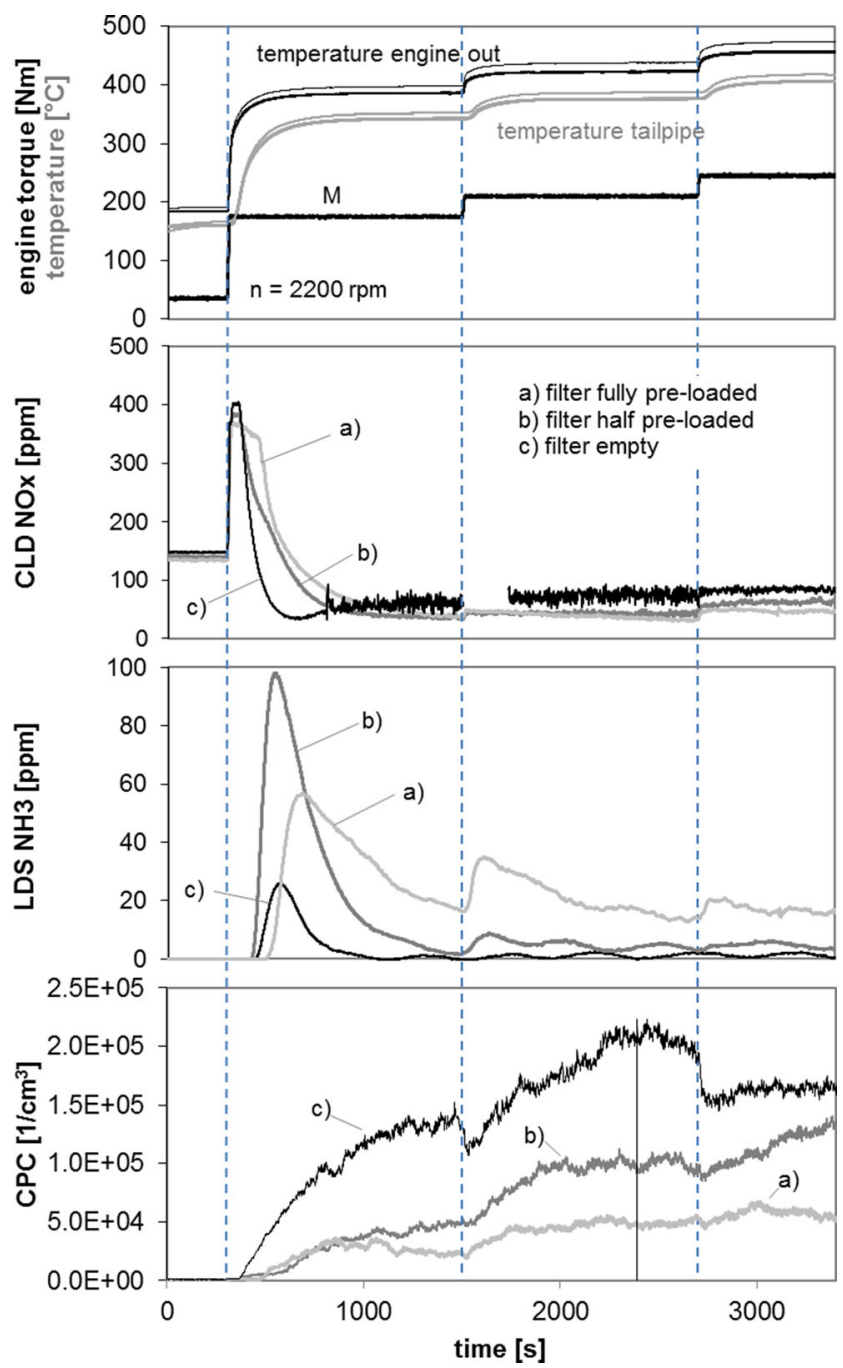

Fig. 6 Comparison of emissions in steps-tests with SDPF at different loadings; SYS03; dosing $\alpha=0.9$

Results of a repeated comparison between fully loaded and empty SDPF are demonstrated again in Fig. 8, which confirms the findings that with higher soot loading of the trap, there are after SWON

- Lower reduction speed of $\mathrm{NO}_{\mathrm{x}}$

- Higher $\mathrm{NH}_{3}$-peak and higher $\mathrm{NH}_{3}$-average values

- Less penetration of secondary nanoparticles

In one test, the SDPF is applied without DOC. Absence of DOC upstream of SDPF deteriorates strongly the deNO $\mathrm{N}_{\mathrm{x}}$ efficiency due to the lack of $\mathrm{NO}_{2}$, but also strongly increases the $\mathrm{NH}_{3}$ concentrations (more than double). Since there is little availability of $\mathrm{NO}_{2}$ and consequently less reactivity of urea, there is a slight increase of secondary (nitric) nanoparticles [28-30].

In another test, the lower AdBlue dosing not only reduces the deNO $\mathrm{N}_{\mathrm{x}}$ efficiency and eliminates $\mathrm{NH}_{3}$ but also causes less NP after SWON.
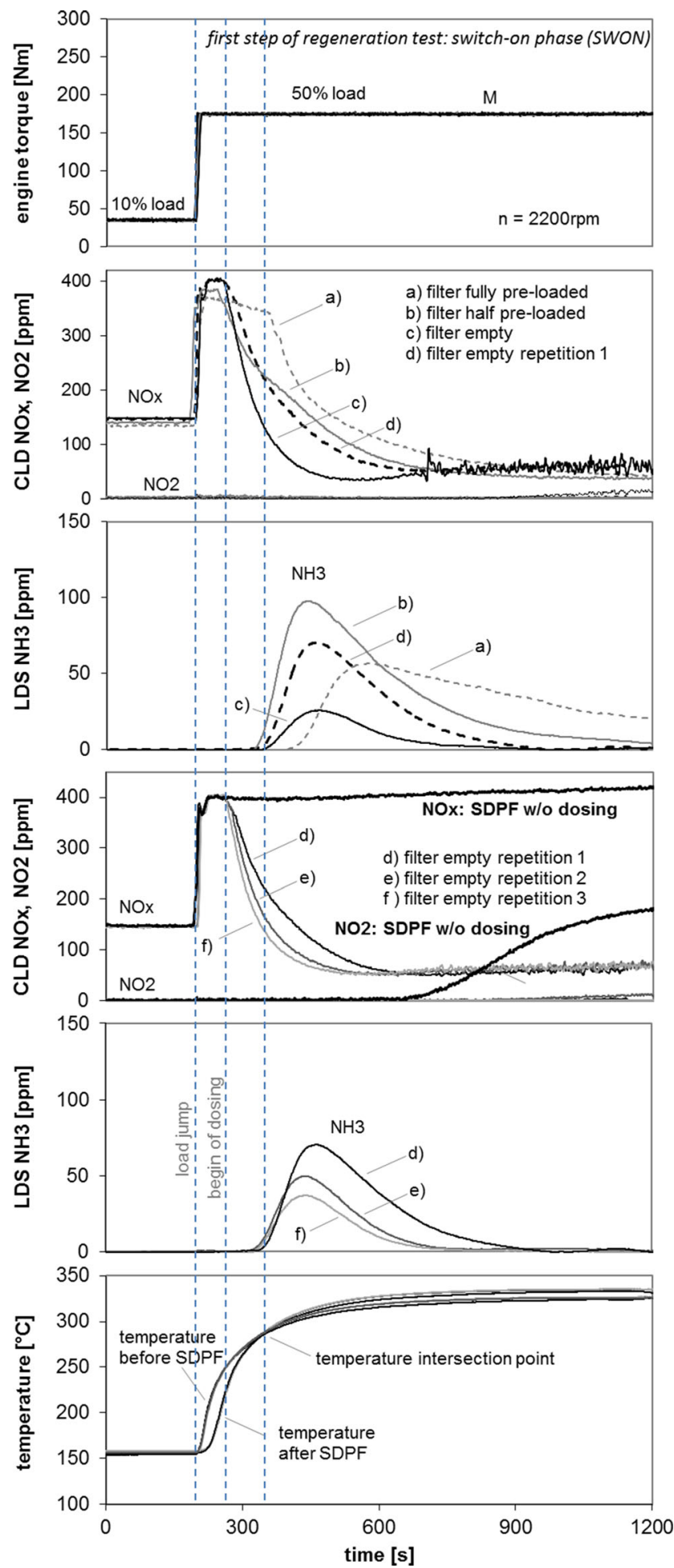

Fig. 7 Repetition of switch-on behavior with empty SDPF; SYS03; dosing $\alpha=0.9$

Table 7 shows the accumulated mass (PM) after the test for those trials. With higher urea dosing, higher mass is accumulated, but without $\mathrm{DOC}$ (without $\mathrm{NO}_{2}$ production), there is the highest mass, which could not be oxidized during the steps-test. 


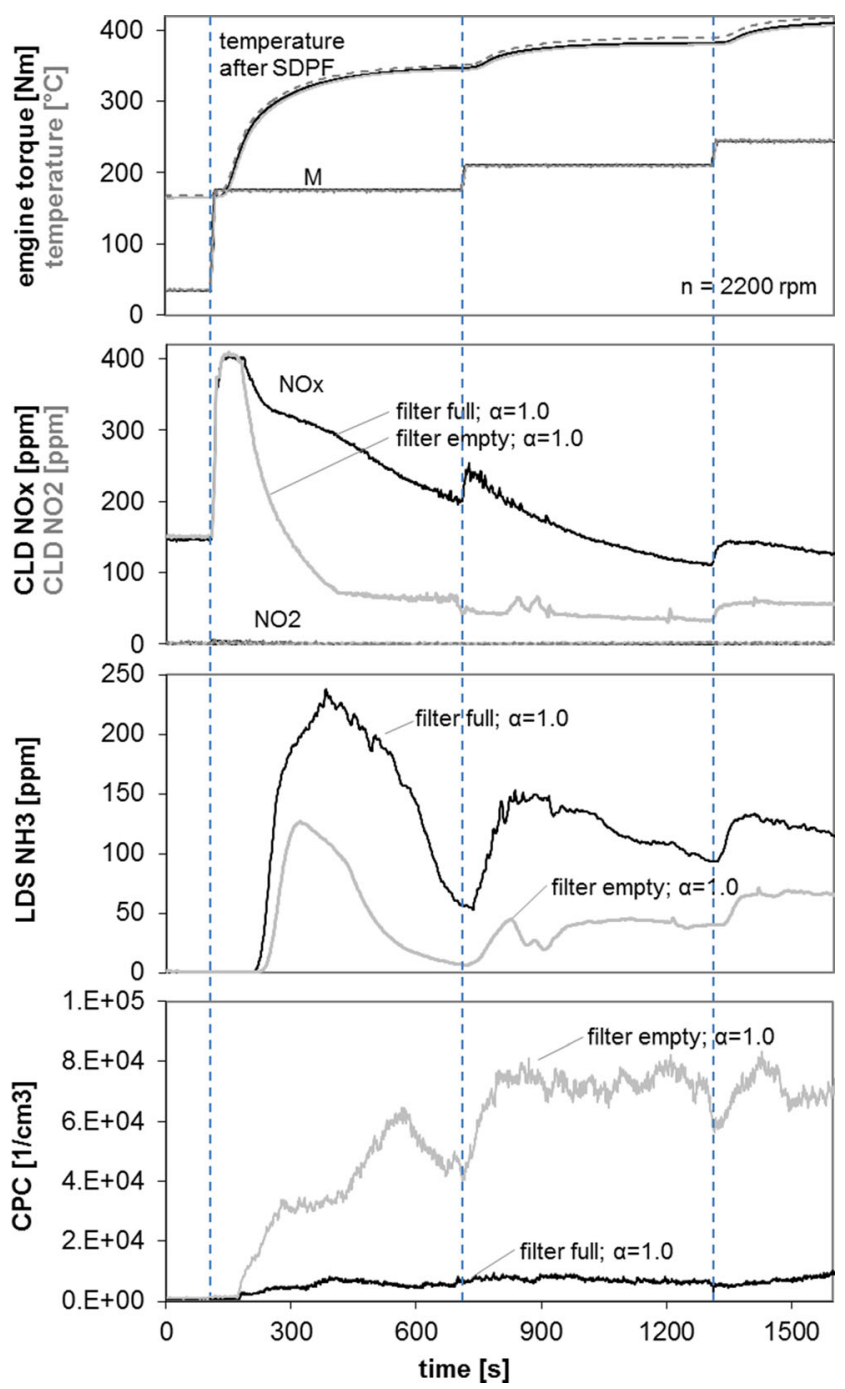

Fig. 8 Repeated comparison of emissions in steps-tests with full and empty SDPF; SYS03; dosing $\alpha=1.0$

\subsection{Nanoparticle Emissions After Urea Switch-on}

As already demonstrated, the NP values (CPC) start to increase after SDPF at the moment of SWON; this is, nevertheless, at a very low level.

The zoomed representation of CPC traces in diverse stepstests, Fig. 10, shows the details of PC increase with different SDPF loadings and with/without RAI.

With more filter pre-loading, the NP counts increase later and attain lower values in the steps-test.

With RAI, PCs increase directly after SWON and stay at a similar level up to the highest (fifth) step.

Without RAI, PCs start to increase in the second or third step, which can be visible according to the representing scale even in the fourth step. In the last step, the PCs w/o RAI increase continuously indicating the increasing penetration through the SDPF. AdBlue dosing clearly inhibits this increased penetration in the two highest steps - the reasons

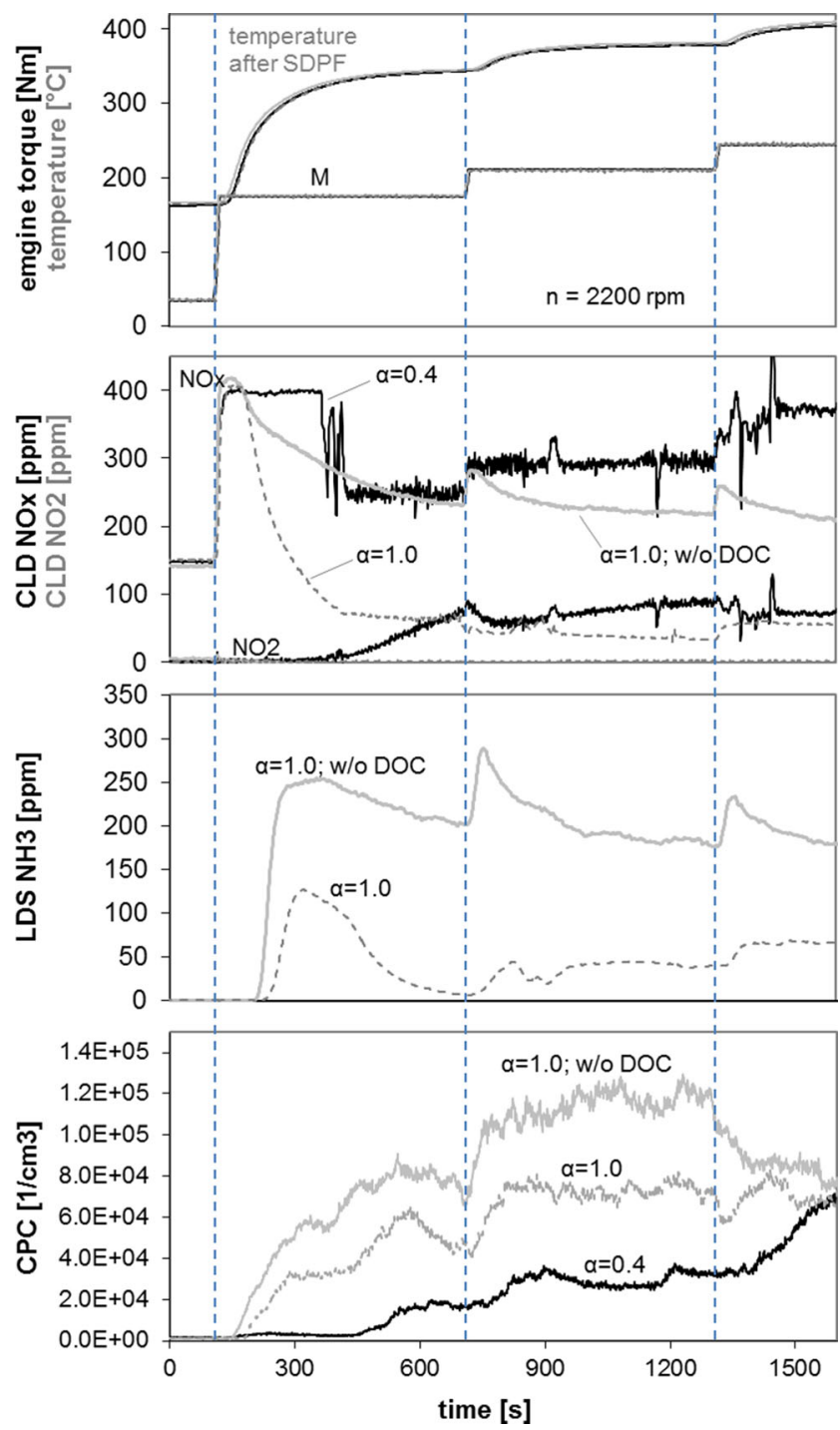

Fig. 9 Comparison of emissions in steps-tests with empty SDPF with and without DOC; SYS03; dosing $\alpha=0.4 / 1.0$

can be reduction of the average temperature of the substrate surface and impact on NP filtration mechanism, like the surface adhesion forces independently on increasing spacial velocity in these higher steps. Since this is a question of secondary (nitric) nanoparticles, which consist mostly of urea and ammonium nitrate crystals, there is an open question of

Table 7 Influence of urea dosing on accumulated mass in empty SDPF during the steps-tests

\begin{tabular}{llll}
\hline Measurement name & $\begin{array}{l}\alpha \\
{[-]}\end{array}$ & $\begin{array}{l}\text { Accum. mass } \\
(\mathrm{g})\end{array}$ & Remarks \\
\hline REGSTEPS21 & 0.4 & 0.1 & \\
REGSTEPS22 & 1 & 6.9 & w/o DOC \\
REGSTEPS23 & 1 & 1.9 & \\
\hline
\end{tabular}

DOC diesel oxidation catalyst 


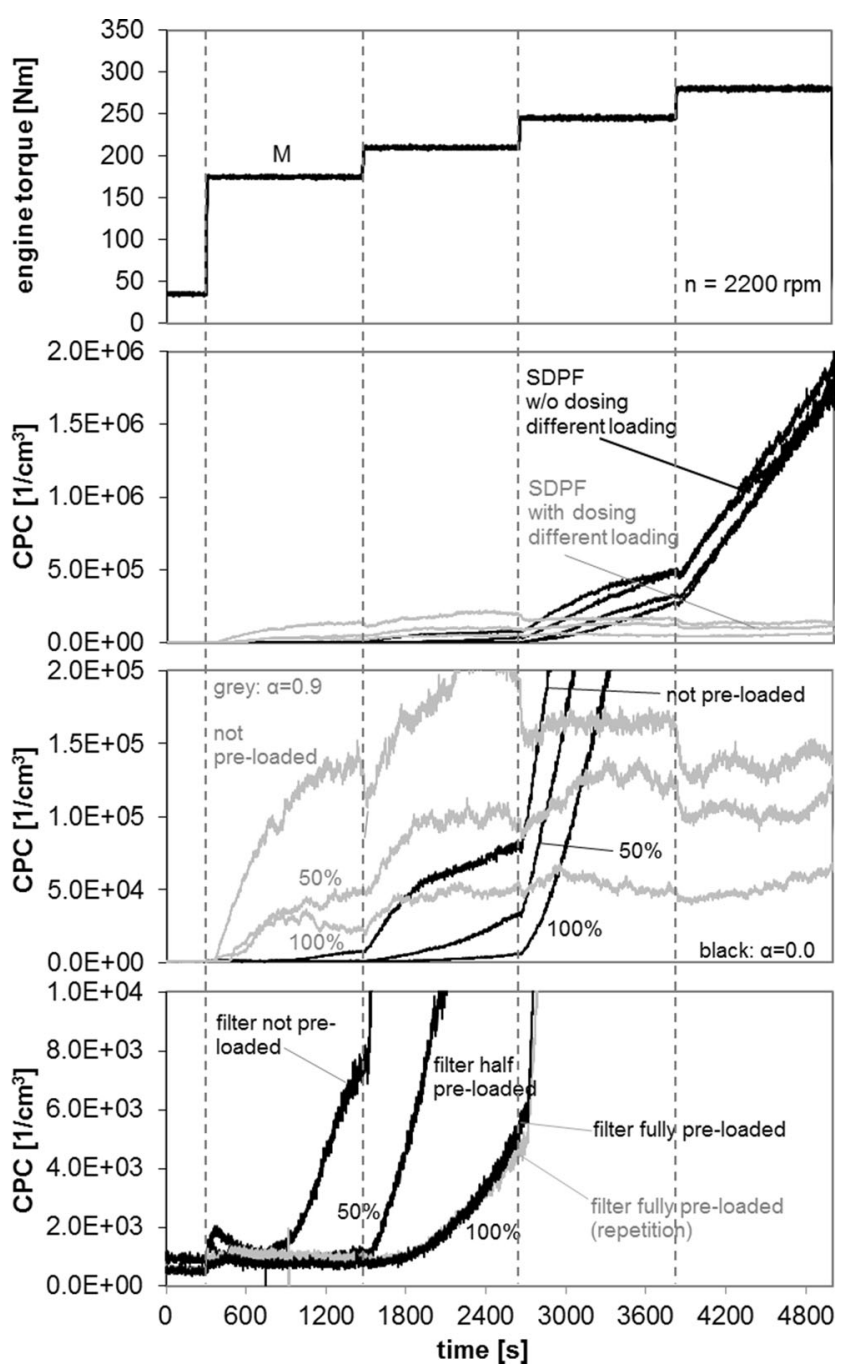

Fig. 10 Nanoparticle emissions in steps-test with SDPF, with/without dosing (zoomed representation); SYS03; dosing $\alpha=0.9$

implication of these nanoparticles or their precursors in the chemical reactions.

Measurements of SMPS particle size distributions (PSDs) were performed with $\mathrm{CDPF}$ and SDPF (systems 1 and 3) at three operating points: $2200 \mathrm{rpm}$ and $35 / 175 / 245 \mathrm{Nm}$, to visualize the effects of secondary nanoparticles with urea dosing.

At the lowest load, urea dosing was not active and, at the highest OPs, it was varied for research.

The performance of tests was according to the identical schedule: starting the engine, heating up at the lowest OP, measurements, and progressing to the middle and after to the highest OP. In this way, the exhaust system was either thermally stabilized or heated up.

Figure 11 shows the example of results with $\mathrm{cDPF}$ (system 1) not pre-loaded at $175 \mathrm{Nm}$. The feed factor $\alpha$ was varied. With increasing urea dosing (after cDPF), the secondary NPs are visible, and the penetration values of entire system increase in the size ranges below $35 \mathrm{~nm}$ and above $250 \mathrm{~nm}$.
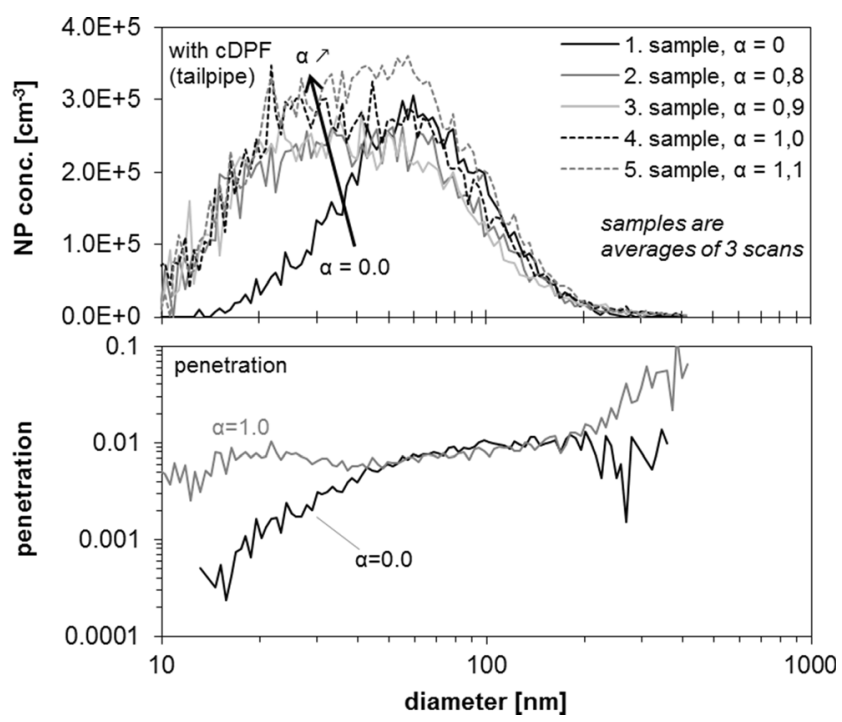

Fig. 11 NP size spectra with conventional DPF+SCR at stationary OP 2200 Nm/175 Nm; SYS01; not pre-loaded

Figure 12 shows the results for SDPF (system 3) not preloaded at $175 \mathrm{Nm}$. The effect of secondary NPs from RAI is clearly demonstrated. The secondary NPs can be seen, even if the RAI is placed upstream of the filter (by cDPF, RAI is downstream of the filter). The urea dosing with $\alpha$ varying from 0.8 to 1.1 has no influence on the concentrations of these secondary NPs.

The maximum values of PC concentrations are with $\mathrm{CDPF}$ significantly higher, than with SDPF. This is due to the fact that with cDPF (SYS 01), the urea dosing is placed downstream of DPF. Nevertheless, in both cases (cDPF and SDPF), the secondary NPs are negligible comparing with the engineout emissions.
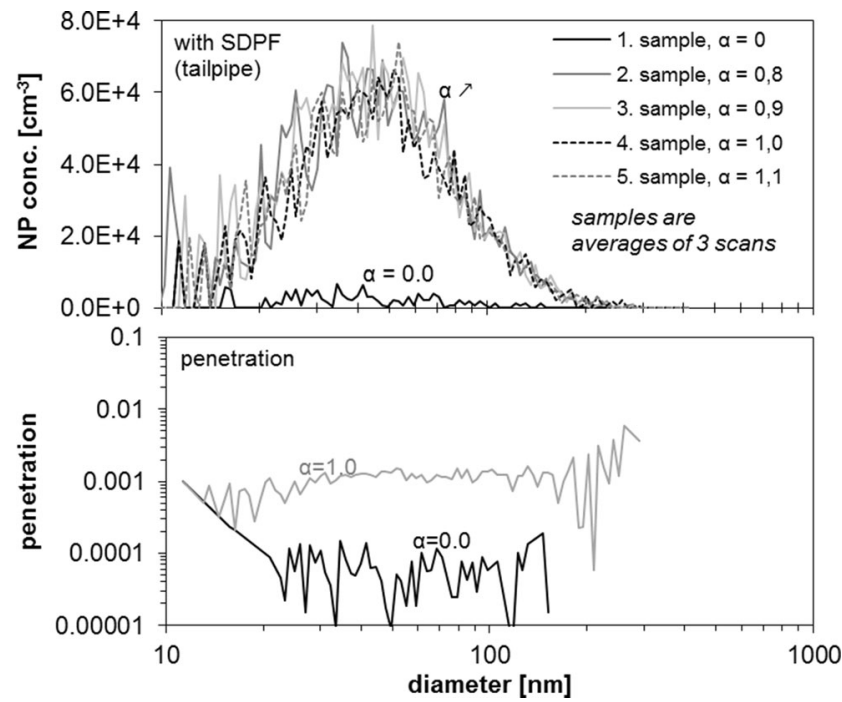

Fig. 12 NP size spectra with SDPF at stationary OP 2200 Nm/175 Nm; SYS03; not pre-loaded 
At the highest OP $(2200 \mathrm{rpm} / 245 \mathrm{Nm})$, both systems showed the increased particle counts due to spontaneous condensates of sulfates [31] (see Fig. 13).

The exhaust gas temperature before (DOC $+\mathrm{cDPF} / \mathrm{SDPF})$ being at this high OP is at $433{ }^{\circ} \mathrm{C}$, which is well sufficient for intense sulfur oxidation in the catalytic system. The sulfates pass in the form of vapors through the trap and then condensate after it, creating increased NP count concentrations. This effect overlaps with the secondary NPs from RAI, which contribute to the seeding effect.

Figure 13 summarizes the NP count concentrations integrated in the size spectrum $20-300 \mathrm{~nm}$ and the resulting particle counts filtration efficiencies (PCFEs).

It can be stated that

- The investigated SDPF has a slightly higher PCFE than the cDPF.

- The urea dosing produces secondary NPs which, nevertheless, have negligible impact on the overall PCFE.

- At high OP (with high $t_{\text {exh }}$ ), there are spontaneous condensates of sulfates, an artifact, which lower the estimated value of PCFE.

\subsection{DeNO Efficiency}

The deNO $\mathrm{N}_{\mathrm{x}}$ efficiency $\left(\mathrm{K}_{\mathrm{NOx}}\right)$ and some interesting emission components $\left(\mathrm{NO}_{\mathrm{x}}, \mathrm{NO}_{2}, \mathrm{~N}_{2} \mathrm{O}\right.$, and $\left.\mathrm{NH}_{3}\right)$ were estimated in steps-tests with cDPF (SYS01) and with SDPF (SYS03). The SDPF was tested with different states of soot loadings.

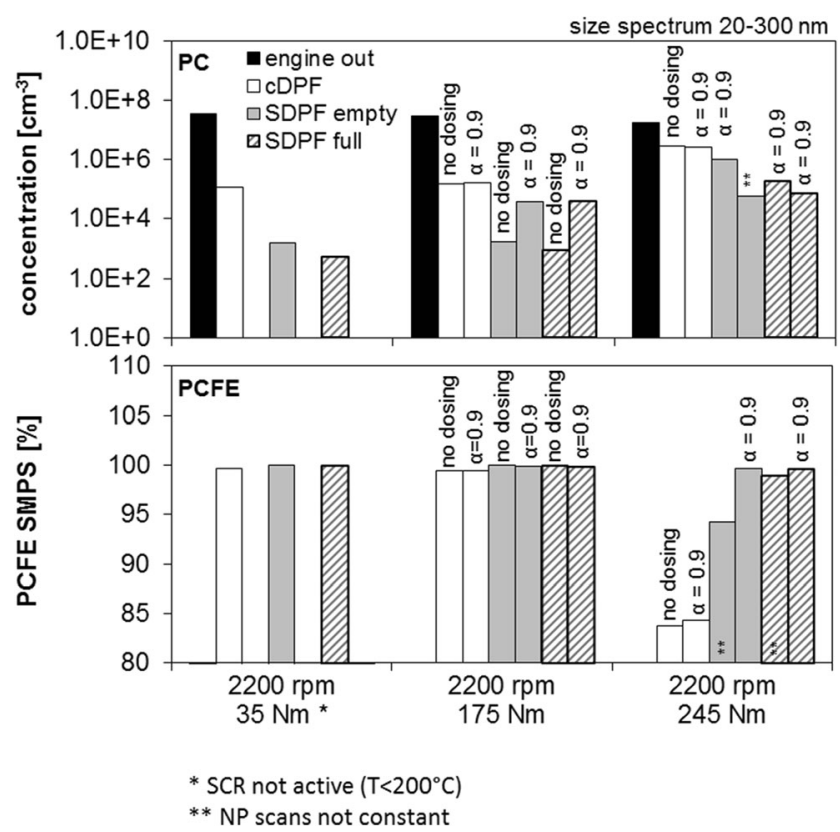

Fig. 13 Particle counts and particle counts filtration efficiency with cDPF and SDPF at stationary OPs; cDPF SYS01 and SDPF SYS03
Figure 14 represents the results at two steps with 175 and $280 \mathrm{Nm}$.

The SDPF with no soot loading has the lowest $\mathrm{K}_{\mathrm{NOx}}$ values (in average $85 \%$ ). This seems to contradict the earlier results (Figs. 6, 7 and 8) showing the quickest $\mathrm{NO}_{\mathrm{x}}$ drop after SWON and the lowest level of $\mathrm{NH}_{3}$ with empty filter. However, in the presented experiments, the engine-out $\mathrm{NO}_{\mathrm{x}}$ level varies; being higher for the empty and lower for the fully-loaded SDPF (see Fig. 6, load jump from the first to the second step). This fact influences the calculated $\mathrm{K}_{\mathrm{NOX}}$ values.

With increased soot loading of SDPF (Fig. 14), the $\mathrm{K}_{\mathrm{NOx}}$ increases to $90 \%$ (average), which is in the same magnitude as for $(\mathrm{cDPF}+2 \times \mathrm{SCR})$.

The increase of $\mathrm{NH}_{3}$ with soot load and active RAI is confirmed for SDPF. The average $\mathrm{N}_{2} \mathrm{O}$ values for SDPF are all below $5 \mathrm{ppm}$. The higher $\mathrm{N}_{2} \mathrm{O}$ value with cDPF was registered only in the first load-jump and it must be associated with a random situation of urea or deposit distribution.

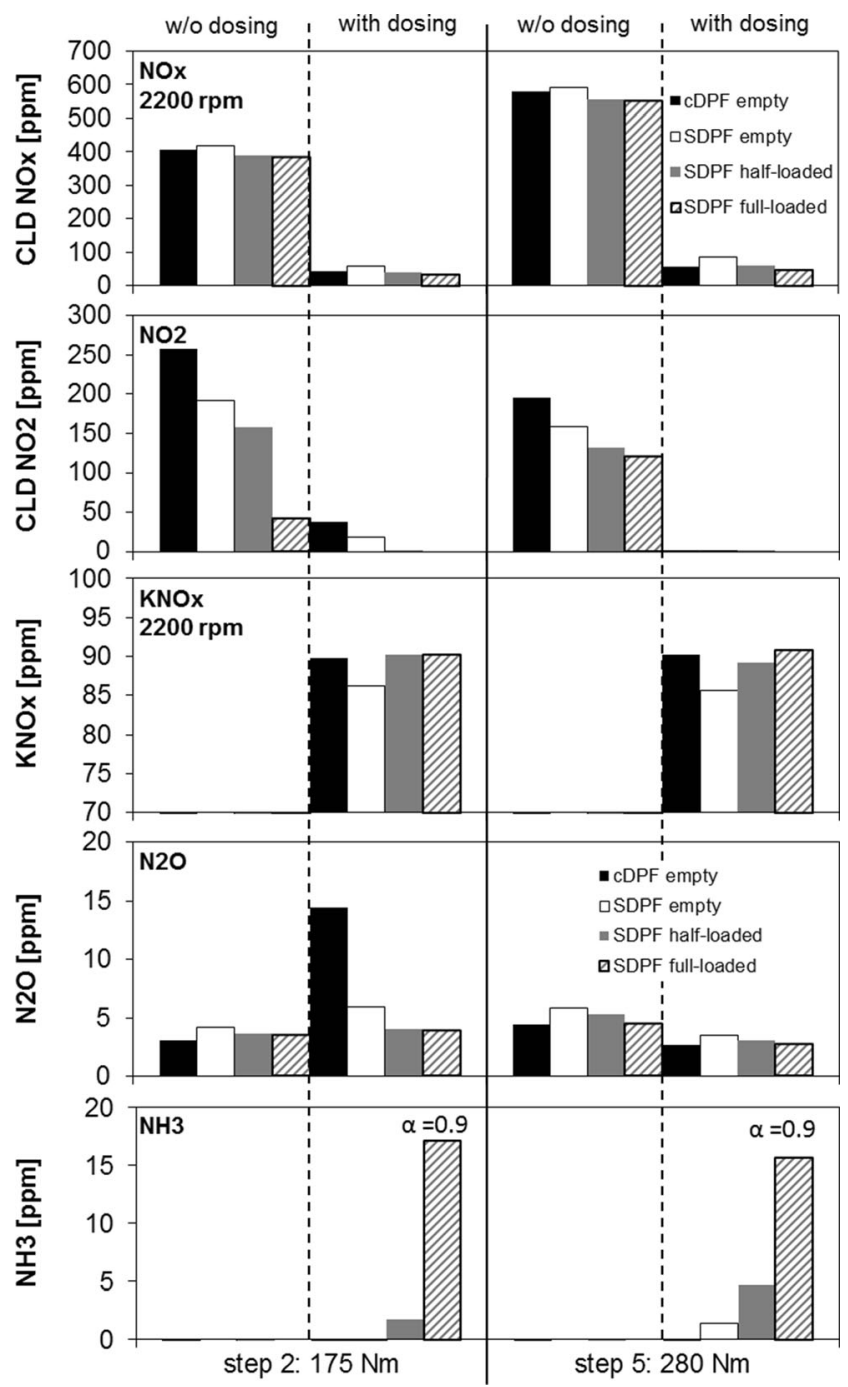

Fig. 14 Average emissions and $\mathrm{K}_{\text {NOx }}$ values in steps 2 and 5; SYS01 and SYS03; filter not pre-loaded; with and w/o dosing $\alpha=0.9$ 
In another experiment, the SCR efficiency $\left(\mathrm{K}_{\mathrm{NOx}}, \mathrm{NO}_{\mathrm{x}}\right.$ conversion, deNO $\mathrm{N}_{\mathrm{x}}$ efficiency, $\mathrm{NO}_{\mathrm{x}}$ reduction rate) was tested with both systems SYS05 with SDPF and SYS01 with $2 \times$ SCR at three different engine loads such as $2200 \mathrm{rpm} / 87 /$ $175 / 280 \mathrm{Nm}$, with variation of feed factor $\alpha$. It was confirmed in these tests that both investigated systems, SDPF and $2 \times$ $\mathrm{SCR}$, attain similar values or $\mathrm{deNO}_{\mathrm{x}}$ efficiency.

\subsection{Dynamic Operation}

After the preparation and testing of the dynamic AdBlue dosing, three WHTC and two ETC tests were performed with SDPF, SYS03, both without and with RAI.

Figure 15 represents the time plots of engine and emission parameters in a part of WHTC, in which a remarkable $\mathrm{NH}_{3}$ peak occurred.
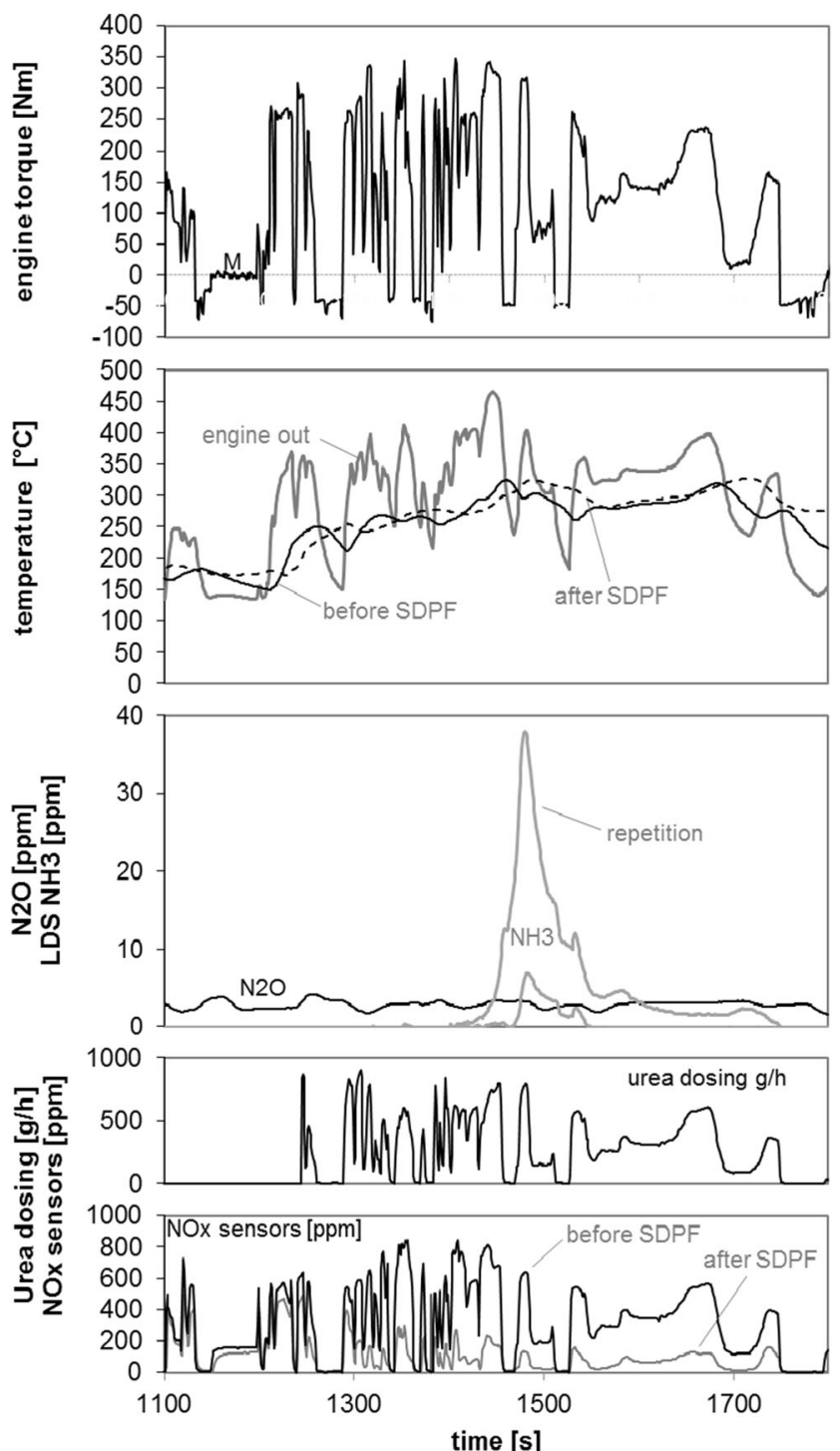

Fig. $15 \mathrm{NH}_{3}$ dispersion in two WHTCs with SDPF; SYS03; not-preloaded; with dosing, $\alpha=0.9$
The precedent operation was conditioning (COND) and $3 \times$ WHTC without urea dosing. Afterward, the two represented WHTC with urea dosing followed directly.

In the identical operation profiles of two WHTCs with RAI, there are different peak values of $\mathrm{NH}_{3}$. These confirm that $\mathrm{NH}_{3}$ emissions depend not only on the operating conditions but also on the state of deposits, soot, nitric deposits, and especially ammonia storage, in the filter.

The average values of results from the performed dynamic driving cycles are represented in Fig. 16.

It can be pointed out that the WHTC with a lower level of exhaust gas temperature has lower $\mathrm{K}_{\mathrm{NOx}}$ values (40-45\% against $75 \%$ in ETC). In ETC with a higher exhaust temperature level, higher $\mathrm{NH}_{3}$ values can be observed.
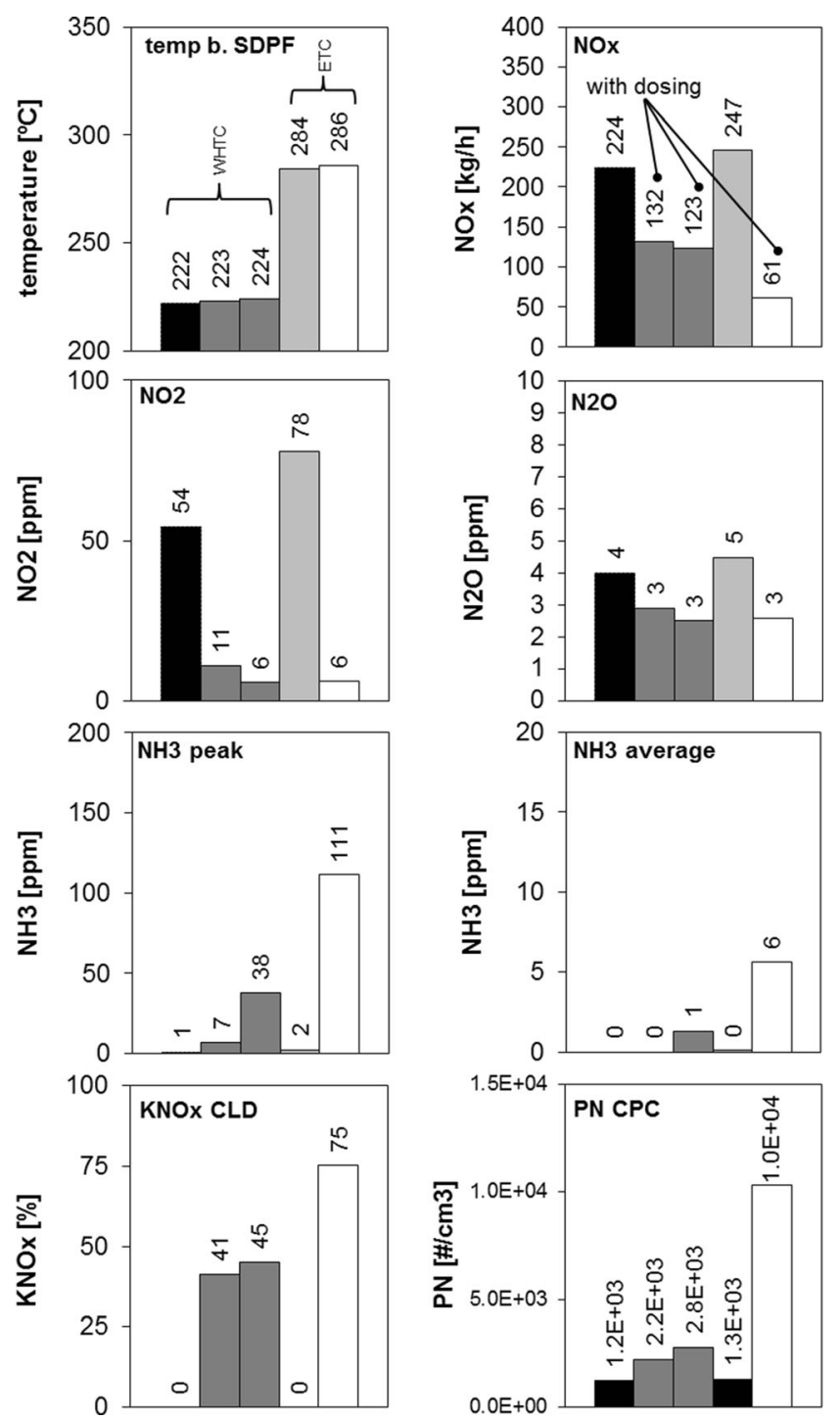

Fig. 16 Average emission and control parameters in dynamic cycles; SYS03; not-pre-loaded; with dosing, $\alpha=0.8$ 


\section{Conclusions}

Several observations and conclusions result from the presented work.

For emissions after SWON, the following can be stated:

- In both systems SCR and SDPF with RAI, there is a reduction of $\mathrm{NO}_{\mathrm{x}}$ and $\mathrm{NO}_{2}$ in the second step.

- With active urea dosing, there are peaks of $\mathrm{N}_{2} \mathrm{O}$ and $\mathrm{NH}_{3}$, as well as a better oxidation of $\mathrm{CO}$ and $\mathrm{HC}$ in the second step, SDPF.

- The emission behavior of SDPF after urea SWON concerning $\mathrm{NO}_{\mathrm{x}}$ reduction speed and $\mathrm{NH}_{3}$ peak is always fluctuating.

- This fluctuation can be explained with the inhomogeneity of urea (and urea products) distribution and the varying initial state of filter in respect of soot loading and soot distribution in the filter volume.

- There is a tendency that the cases with quicker $\mathrm{NO}_{\mathrm{x}}$ drop after SWON have also a lower $\mathrm{NH}_{3}$ emission.

The presence of secondary nitric nanoparticles (NPs) with urea dosing is a known effect, but it has a negligible impact on the particle counts filtration efficiency (PCFE) of the entire system. With RAI upstream of SDPF, the level of secondary particle counts is 1 order of magnitude lower, than with RAI downstream of cDPF. Some specific points concerning NP can be remarked:

- The emissions of secondary NP counts CPC start to increase with SDPF from the instant of SWON even with a very low level.

- With more filter pre-loading, the NP counts increase later and bring down values in the steps-test.

- At high OP (with high $t_{\text {exh }}$ ), there are spontaneous condensates of sulfates, which lower the estimated value of PCFE.

The most important remarks concerning the deNO $\mathrm{N}_{\mathrm{x}}$ efficiency $\left(\mathrm{NO}_{\mathrm{x}}\right.$ conversion rate $\left.\mathrm{K}_{\mathrm{NOx}}\right)$ are as follows:

- Operation without DOC upstream of SDPF (no $\mathrm{NO}_{2}$ production) deteriorates the $\mathrm{NO}_{\mathrm{x}}$ conversion, increases the $\mathrm{NH}_{3}$ emissions, and reduces the portion of $\mathrm{PM}$, which is oxidized in the SDPF.

- The loaded SDPF, compared with empty one, shows slower $\mathrm{NO}_{\mathrm{x}}$ reduction and higher $\mathrm{NH}_{3}$ after SWON due to the use of part of $\mathrm{NO}_{2}$ for soot oxidation and consequently less $\mathrm{NO}_{2}$ availability for the deNO $\mathrm{N}_{\mathrm{x}}$ reactions; the secondary NP penetration after SWON is clearly lower with the loaded trap.

- Both investigated systems, SDPF and $2 \times$ SCR, attain nearly the same deNO $\mathrm{x}_{\mathrm{x}}$ efficiency $\left(\mathrm{K}_{\mathrm{NOx}}\right)$.
- The highest $\mathrm{K}_{\mathrm{NOx}}$ values are to be obtained at stoichiometric urea dosing, but to minimize the $\mathrm{NH}_{3}$ slip, it is recommended to avoid passing over feed factor of $\alpha=0.9$.

In dynamic operation in the WHTC with a lower level of exhaust gas temperature, lower $\mathrm{K}_{\mathrm{NOx}}$ values (40-45\% against $75 \%$ in ETC) and also lower $\mathrm{NH}_{3}$ emissions with SDPF are resulting.

Different $\mathrm{NH}_{3}$ peaks (with RAI at WHTC) in the identical operation profiles indicate that $\mathrm{NH}_{3}$ emissions depend not only on the operating conditions but also on the state of deposits in the filter.

The presented observations and results warrant further research in the future, specifically aimed at the following:

- Studying in more detail the interaction of urea/ $\mathrm{NH}_{3}, \mathrm{NO}_{2}$, and the accumulated soot

- Further analysis of reasons for fluctuating results after SWON

- Explaining of lower penetrations of secondary NP with active RAI and SDPF

- The ash and soot loading and the regeneration in different dynamic test cycles

Acknowledgments The authors want to express their gratitude to the Swiss Federal Office of Environment BAFU and Liebherr Machines SA, Bulle, $\mathrm{CH}$, for the financial support and realization of the project, and project partners for supplying test material and valuable discussions.

\section{References}

1. Frank, W., Hüthwohl, G. Maurer, B.: SCR-Technologie für Nutzfahrzeuge. Purem Abgassysteme GmbH, MTZ 9/2004, S. 632

2. Lambert, Ch., Hammerle, R., Mc Gill, R., Khair, M., Sharp, Ch.: Technical Advantages of Urea SCR for Light-Duty and HeavyDuty Diesel Vehicle Applications. Ford Research, Oak Ridge National Laboratory, Southwest Research Institute, SAE Paper 2004-01-1292

3. Hinz, A., Jarvis, T., et al.: Field Test Trucks Fulfilling EPA '07 Emission Levels On-Road by Utilizing the Combined DPF and Urea-SCR System. Volvo, Johnson Mattey, Chevron, Bosch, SAE Techn. Paper 2006-01-0421

4. Arrowsmith, D., Bott, A., Busch, Ph.: Development of a Compact Urea-SCR + CRT System for Heavy-Duty Diesel Using a Design of Experiments Approach. Eminox Ltd., SAE Techn. Paper 2006-010636

5. Rusch, K., Kaiser, R., Hackenberg, S.: DPF SCR Combinations Integrated Systems to Meet Future LDV Emission Limits. Arvin Meritor, SAE Techn. Paper 2006-01-0637

6. Hümekes, E., Neubauer, T., Roth, S., Patchett, J.: Selective Catalytic Reduction (SCR) for Mobile Application - Heavy Duty Diesel. Engelhard. 4th International Exhaust Gas and Particulate Emissions Forum, AVL, Ludwigsburg, 109 March 2006

7. Jacob, E., Müller, R., Scheeder, A., Cartus, T., Dreisbach, R., Mai, H.-P., Paulus, M., Spengler, J.: High Performance SCR Catalyst System: Elements to Guarantee the Lowest Emissions of $\mathrm{NO}_{\mathrm{x}}$. 27. Internationales Wiener Motorensymposium, Bd.2 2006 
8. Cartus, T., Schüssler, M., Herrmuth, H., Giovanella, M.: SCR and DPF - From Concept to Production. Mastering Complex, MutliDimensional Challenges. 28. Internationales Wiener Motorensympo-sium. Bd.1 2007

9. Willems, F., Cloudt, R., van den Eijnden, E., van Genderen, M., Verbeek, R., de Jager, B., Boomsma, W., van den Heuvel, I.: Is Closed-Loop SCR Control Required to Meet Future Emission Targets? SAE Techn. Paper 2007-01-1574

10. Pischinger, S., Körfer, T., Wiartalla, A., Schnitzler, J., Tomazic, D., Tatur, M.: Combined Particulate Matter and $\mathrm{NO}_{\mathrm{x}}$ Aftertreatment Systems for Stringent Emission Standards. SAE Techn. Paper 2007-01-1128

11. Hosoya, M., Kawada, Y., Sato, S., Shimoda, M.: The Study of $\mathrm{NO}_{\mathrm{x}}$ and PM Reduction Using Urea Selective Catalytic Reduction System for Heavy Duty Diesel Engine. SAE Techn. Paper 2007-01-1576

12. Görsmann, C.: Retrofit SCRT ${ }^{\circledR}-$ A retrofit system for the simultaneous reduction of carbon monoxide, hydrocarbon, soot particulate and oxides of nitrogen emissions from commercial vehicles, 4. FAD - Konferenz, Dresden, p. 155. November 2006

13. Girard, J-W., Cavataio, G., Lamber, Ch. K.: The Influence of Ammonia Slip Catalysts on Ammonia, $\mathrm{N}_{2} \mathrm{O}$ and $\mathrm{NO}_{\mathrm{x}}$ Emissions for Diesel Engines. SAE Techn. Paper 2007-01-1572

14. Xu, L., Watkins, W., Snow, R., Graham, G., McCabe, R., Lambert, Ch., Carter III, R.O.: Laboratory and Engine Study of Urea-Related Deposits in Diesel Urea-SCR After-Treatment Systems. SAE Techn. Paper 2007-01-1582

15. Girard, J., Snow, R., Cavataio, G., Lambert, Ch.: The Influence of Ammonia to $\mathrm{NO}_{\mathrm{x}}$ Ratio on SCR Performance. SAE Techn. Paper 2007-01-1581

16. Hoard, J., Snow, R., Xu, L., Gierczak, Ch., Hammerle, R., Montreuil, C., Farooq, S.I.: $\mathrm{NO}_{\mathrm{x}}$ Measurement Errors in Ammonia-Containing Exhaust. SAE Techn. Paper 2007-01-0330

17. Shah, S.D., Mauti, A., Richert, J.F.O., Loos, M.J., Chase, R.E.: Measuring $\mathrm{NO}_{\mathrm{x}}$ in the Presence of Ammonia. SAE Techn. Paper 2007-01-0331

18. Shah, S.D., Mauti, A., Richert, J.F.O., Chase, R.E.: The Oxidation of NO to Yield NO2 in Emissions Testing Sample Bags. SAE Techn. Paper 2007-01-0332

19. Jacob, E.: Perspektiven der mobilen SCR-Technik, 15. Aachener Kolloquium Fahrzeug- und Motorentechnik S. 13032006

20. Cavataio, G., Girard, J., Patterson, J.E., Montreuil, C., Cheng, Y., Lamber, Ch. K.: Laboratory Testing of Urea-SCR Formulations to Meet Tier 2 Bin 5 Emissions. SAE Techn. Paper 2007-01-1575
21. Mauer, B., Lücking, Ch., Hüthwohl, G.: ADSTM, ein druckluftfreies System zur Dosierung von AdBlue ${ }^{\circledR}$ - Neue Perspektiven für die SCR Technologie. 15. Aachener Kolloquium Fahrzeug- und Motorentechnik, S. 13372006

22. Döring, A., Emmerling, G., Rothe, D.: Downsizing of the Euro VI exhaust aftertreatment components to fit into the Euro III silencer. MAN Nürnberg, D, 33. International Vienna Engine Symposium, tom 2, p. 2582012

23. Tan, W., Youngren, D., SantaMaria, M., Kumar, S.: On-Engine Investigation of SCR on Filters (SCRoF) for HDD Passive Applications. SAE Techn. Paper 2013-01-1066, Detroit 2013

24. Cavataio, G., Girard, J., Lambert, C.: Cu/Zeolit SCR on Hight Porosity Filters: Laboratory and Engine Performance Evaluations. SAE Techn. Paper 2009-01-0897, Detroit 2009

25. Naseri, M., Chatterjee, S., Castagnola, M., Chen, H., et al.: Development of SCR on diesel particulate filter system for heavy duty applications. SAE Int. J. Engines 4(1), 1798-1809 (2011). doi: 10.4271/2011-01-1312

26. Schrade, F., Brammer, M., Schaeffner, J., Langeheinecke, K., et al.: Physico-chemical modeling of an integrated SCR on DPF (SCR/ DPF) system. SAE Int. J. Engines 5(3), 958-974 (2012). doi:10. 4271/2012-01-1083

27. Smedler, G., Johansson, A., Thorén, A., Larsson, M., Genschow, T., Sonntag, O., Arulraj, K., Bhantoo, J., Newman, C.: Particulate Emissions from Modern Exhaust Aftertreatment Systems - Effects of System Layout and Catalytic Coating Deposition on Gaseous Emissions, Particulate Number and Back Pressure. 8th International Exhaust Gas \& Particulate Emissions Forum, AVL, 1-2 April 2014

28. Czerwinski, J., Zimmerli, Y., Mayer, A., Heeb, N., Lemaire, J., D'Urbano, G., Bunge, R.: Testing of Combined DPF+SCR Systems for HD-Retrofitting -VERTdePN. SAE Technical Paper 2009-01-0284, Detroit, April 2009

29. Czerwinski, J., Zimmerli, Y., Mayer, A., Heeb, N., D’Urbano, G.: Diesel Emission with DPF+SCR in VERTdePN-Testing \& Potentials. SAE Paper 2011-01-1139, Detroit, April 2011

30. Czerwinski, J., Zimmerli, Y., Mayer, A., Heeb, N., Lemaire, J., D'Urbano, G.: VERTdePN Quality Test Procedure of DPF+SCR systems. SAE Technical Paper 2014-01-1579, Detroit, April 2014

31. Mayer, A., Ulrich, A., Heeb, N.V., Czerwinski, J., Neubert, T.: Particle Filter Properties after 2000 hrs Real World Operation, SAE Techn. Paper SAE 2008-01-0332 